Anna Kolbuk

Witold Kolbuk

\title{
Próba przejęcia przez prawosławie parafii unickich w Kongresówce w latach 1840-1842
}

Od unicestwienia państwowości polskiej władze rosyjskie konsekwentnie dążyły do skasowania unii cerkiewnej na ziemiach dawnej Rzeczypospolitej. Zrywanie łączności z Rzymem odbywało się niejako etapami, wyznaczanymi przez „nawracanie” unitów na prawosławie w Imperium Rosyjskim najpierw w latach 1793-1796, a potem w roku 1839 , kiedy to ostatecznie zlikwidowano unię za Bugiem. Tym samym jedynym miejscem, w którym „obrządek grecko-unicki”’ mógł funkcjonować pod panowaniem Romanowów, stała się diecezja chełmska w Królestwie Polskim². Ten stan rzeczy miał jednak charakter tymczasowy, o czym świadczyły działania wobec duchownych i wiernych unickich, podejmowane przez władze rosyjskiej Cerkwi prawosławnej w ścisłej współpracy z przedstawicielami administracji carskiej.

Lojalność okazywana wobec caratu przez ówczesnego biskupa chełmskiego Filipa Felicjana Szumborskiego (1830-1851) i jego neutralna postawa w czasie ,polskiej rewolucji” w latach $1830-1831^{3}$, a także wprowadzone przez niego pewne zmiany w liturgii jego Cerkwi, upodabniające ją zewnętrznie do nabożeństw sprawowanych przez prawosławnych ${ }^{4}$, ani imputowana hierarsze - w tajnych raportach - ,słabość charakteru", nie były dla władz gwarancją szybkiego przejęcia przez „obrządek greko-rosyjski” struktur cerkiewnych, duchowieństwa oraz wiernych. Dlatego też wobec biskupa i jego otoczenia podejmowano szereg działań mających skłonić go do jak najszybszego i najpełniejszego podporządkowania diecezji, ,wyznaniu

\footnotetext{
${ }^{1}$ Nazwa przyjęta w nomenklaturze urzędowej po 1830 r., która miała na celu m.in. semantyczne zacieranie różnic między wyznaniem prawosławnym tj. rosyjską Cerkwią prawosławną, a obrządkiem greckim Kościoła katolickiego.

${ }^{2}$ W. Kołbuk, Kościoły wschodnie na ziemiach dawnej Rzeczypospolitej 1772-1914, Lublin 1992, s. $17-19$.

${ }^{3}$ J. P. Bojarski, Czasy Nerona w XIX wieku pod rzadem moskiewskim czyli ostatnie chwile unii $w$ diecezji chetmskiej, Lwów 1878, s. 9 i nn.

${ }^{4}$ Wprowadzone listem pasterskim, w taki sam sposób wycofane (m.in. pod naciskiem Stolicy Apostolskiej), por. J. P. Bojarski, Czasy Nerona, s. 18-22.

${ }^{5}$ Tamże, s. 13-14.
} 
rosyjskiemu”. Temu celowi miał służyć m.in. pobyt biskupa ${ }^{6}$ (na osobiste zaproszenie cara) w Petersburgu, w czasie którego próbowano, różnymi sposobami, przekonać chełmskiego hierarchę do ,nieskażonej” wiary prawosławnej ${ }^{7}$. Nie przyniosło to jednak spodziewanego efektu - biskup Szumborski kontynuował przyjęty przez siebie sposób kierowania diecezją, m.in. poprzez osobiste wizytacje parafii, w czasie których apelował o wytrwałość w wierze przodków ${ }^{8}$. Nie zmienił również (wbrew sugestiom władz) swoich współpracowników9.

Wobec niemożliwości przekonania najważniejszych osób w diecezji do zerwania łączności z Rzymem, władze rosyjskie (tak świeckie, jak i duchowne) rozpoczęły, jeszcze w trakcie pobytu biskupa Szumborskiego w stolicy, inne działania ${ }^{10}$ zmierzające do przejęcia przez obrządek grecko-rosyjski pojedynczych parafii unickich. Przedmiotem zainteresowania władz miały stać się trzy wiejskie parafie: Luchów, Babice i Potok Górny położone w południowej części diecezji, w dekanacie tarnogrodzkim $^{11}$, blisko granicy z Galicją ${ }^{12}$. Choć jest rzeczą nieco ryzykowną wyciąganie z tego daleko idących wniosków, to owa bliskość Galicji mogła sugerować pewne powiązania zdarzeń na tym terenie z niezbyt jeszcze sprecyzowanymi społeczno-narodowymi inicjatywami duchowieństwa galicyjskiego ${ }^{13}$. Można też domniemywać, że próba ,przeciągnięcia” unitów na prawosławie na tym terenie wiązała się z silniej tu narastającymi oczekiwaniami chłopstwa na zmianę stosunków własnościowych (uwłaszczenie, likwidacja pańszczyzny), które to nadzieje bliższe były spełnienia w Galicji, niż w Kongresówce. Pod zaborem rosyjskim w tym czasie myślano zaledwie o powstrzymaniu ,rugowania” chłopów z użytkowanych przez nich gospodarstw $^{14}$.

${ }^{6}$ Lipiec 1840 - styczeń 1841.

${ }^{7}$ Zob. Dziennik podróży do Petersburga Filipa Szumborskiego z roku 1840, wyd. A. Petrani, ,Archiwa, Biblioteki i Muzea Kościelne”, t. 13, 1966, s. 269-300.

${ }^{8}$ Archiwum Państwowe w Lublinie (dalej: APL), Chełmski Konsystorz Greckokatolicki (dalej: ChKGK), sygn. 27 (Akta osobowe biskupa Szumborskiego), s. 8-15 (,Wizyty jeneralne w Diecezji Chełmskiej odprawione, także Cerkwie konsekrowane i różne podróże odbyte w sprawach duchownych...").

${ }^{9}$ Likowski E. Ks., Dzieje Kościoła unickiego na Litwie i Rusi w XVIII i XIX wieku uważane głownie ze względu na przyczyny jego upadku, Poznań 1880, s. 363-365; Bojarski, s. 17-22.

${ }^{10}$ Do ,innych działań” w znaczeniu ogólno diecezjalnym należy również zaliczyć - nie omawiane tu - prześladowania kleryków chełmskiego seminarium (lata 30. i 40. XIX w., zob. Akta śledcze tajnego towarzystwa „Fraternitas” zawiazanego w Chetmie $w 1840$ roku, wyd. F. Ramontowska, ,Przegląd Historyczny", 1979, t. 70, s. 307) i późniejsze wobec zakonu bazylianów (od lat czterdziestych), zob. J. P. Bojarski, Czasy Nerona, s. 14, 23, Likowski, s. 366-367.

${ }^{11}$ APL, ChKGK, sygn. 227 (Dek. tarnogrodzki). Do 1809 r. dekanat ten należał do diecezji przemyskiej, zob. Archiwum Państwowe w Przemyślu (dalej: APP), Archiwum Biskupstwa Grecko-Katolickiego (dalej: ABGK), sygn. 54, k. 4-8, sygn. 212,k. 457-458.

${ }_{12}$ Zob. Stownik Geograficzny Królestwa Polskiego i innych Krajów Słowiańskich (dalej: SGKP), red. F. Sulimirski, B. Chlebowski, W. Walewski, t. 1, Warszawa 1880, s. 68 (Babice), t. 5, Warszawa 1885, s. 459 (Luchów), t. 8, Warszawa 1888, s. 866 (Potok Górny).

${ }_{13}$ Zob. J. Kozik, Ukraiński ruch narodowy w Galicji w latach 1830-1848, Kraków 1973.

${ }^{14}$ M. Zgórniak, Polska w czasach walk o niepodległość (1815-1864), w: Wielka Historia Polski, red. S. Grodziski i in., Kraków 2001, t. 7, s. 178-179. 
Luchów od końca lat osiemdziesiątych XVIII w. nie był de facto samodzielną parafią - pod rządami austriackimi został przyłączony do cerkwi parafialnej w Tarnogrodzie $^{15}$, jako jej filia i szybko stracił na znaczeniu. Nie figurował już w spisach podatkowych i majątkowych z pierwszych lat istnienia diecezji chełmskiej w nowym kształcie $^{16}$. Wieś Luchów, co miało się okazać kluczowe dla późniejszych wydarzeń, znajdowała się na terenie dawnego starostwa tarnogrodzkiego, przechodzącego po rozbiorach w ręce kolejnych zarządców „,dóbr narodowych"17.

Potok Górny (nazywany też Ordynackim) położony był w kluczu lipińskim ${ }^{18}$ Ordynacji Zamojskiej. Był parafią średnio zamożną ze średnimi dochodami ${ }^{19}$ - według różnych spisów - od 41 zł $^{20}$ do 106 zł 12 gr²1, zamieszkaną przez ok. 700 osób (głównie unitów) ${ }^{22}$. Na przełomie lat trzydziestych i czterdziestych probostwo to istniało już tylko „na papierze”, ponieważ zrujnowana, grożąca zawaleniem cerkiew potocka w 1839 r. została zamknięta, a wierni spełniali praktyki religijne w świątyni w Lipinach ${ }^{23}$.

Najwięcej informacji posiadamy o parafii w Babicach - miejscu najbardziej dramatycznych, a jednocześnie najlepiej udokumentowanych, wydarzeń związanych z przejmowaniem cerkwi i parafii przez prawosławną administrację. Okręg parafialny Babice, położony na wschód od pozostałych wymienionych miejscowości, na początku lat czterdziestych XIX w. obejmował wsie Babice i Różaniec ${ }^{24} \mathrm{w}$ gminie i kluczu Łukowa Ordynacji Zamojskiej. Według spisu z 1825 r. praktyki religijne w cerkwi unickiej wypełniało ok. 700 osób spośród 970 mieszkańców ${ }^{25}$. Mimo ciągnącego się latami i wciąż nierozstrzygniętego sporu z rzymskokatolicką parafią w Tarnogrodzie o pobór mesznego z Różańca ${ }^{26}$ sytuacja materialna probostwa

${ }^{15}$ APP, ABGK, sygn. 212, k. 2-3.

${ }^{16}$ Por. APL, ChKGK, sygn. 227, k. 20 (1820), k. 78 v.-79 (1833 r. wspomniane 1/2 łanu i ogród jako część uposażenia proboszcza tarnogrodzkiego).

${ }_{17}^{17}$ SGKP, t. 5, s. 459.

${ }^{18}$ Czyli zarazem w gminie Lipiny.

${ }^{19}$ Swoje przychody beneficjum zawdzięczało dziesięcinie w wysokości 40 kop zboża i 4 korców hreczki oraz ok. 62 morgom gruntów, zob. APL, ChKGK, sygn. 227, k. 77v.-78 (1833), sygn. 151, k. 372v. (1841), APL, Archiwum Ordynacji Zamoyskiej (dalej: AOZ), sygn. 3465 (Zamiana gruntów), k. $6 \mathrm{v}$.

${ }^{20}$ W 1823 r. (APL, ChKGK, sygn. 147, k. 214v.-215).

${ }^{21} \mathrm{Wg}$ spisu z 1816 r. (APL, ChKGK, sygn. 227, k. 9v.-10).

${ }^{22}$ W 1823 r. 682 „dusze” obrządku unickiego (APL, ChKGK, sygn. 147, k. 214v.-215).

23 APL, ChKGK, sygn. 151, k. 170v.-171; SGKP, t. 8, s. 866.

${ }^{24}$ Od 1811 r. Różaniec (z wsią Wola Różaniecka) był filią (APL, ChKGK, sygn. 283, k. 11). Tego dekretu biskupa nie przyjmował do wiadomości ksiądz unicki z Tarnogrodu, zgłaszający przez wiele lat pretensje do dochodów z Różańca, które szacował na 98 zł z dziesięciny, 120 zł ze zbioru siana i 195 zł z gruntu (zob. APL, ChKGK, sygn. 282, k. 2).

${ }^{25}$ Nie wiadomo ilu dokładnie było unitów, ilu łacinników, prawdopodobnie zdarzały się też małżeństwa mieszane obrządkowo, co komplikowało obliczenia (APL, ChKGK, s. 283, k. 35). Według spisu państwowego z 1827 r. w samych Babicach w 142 domach mieszkały 754 osoby (SGKP, t. 1, s. 68).

${ }^{26}$ Spór ten rozpoczął się w czasie regulacji dziesięcin w dobrach Ordynacji, a wymiana związanej z nim korespondencji (na niemal wszystkich szczeblach władz duchownych i świeckich) nie przyniosła żadnych konkretnych ustaleń (APL, ChKGK, sygn. 282, k. 45-61v.). 
babickiego przedstawiała się bardzo korzystnie. Żyzne pola i łąki ${ }^{27}$, regularny dopływ danin ${ }^{28}$ i kompetencja ${ }^{29}$, czyli rodzaj stałej pensji wypłacanej proboszczowi przez państwo, oraz stan samej cerkwi i zabudowań plebalnych ${ }^{30}$ sprawiały, że Babice były jedną z najbogatszych parafii w całej diecezji chełmskiej. Według spisów z 1818 i 1832 r. wszystkie realności i stużebności przynosiły średni dochód w wysokości 508 zł $7 \mathrm{gr}^{31}$, według tychże zestawień beneficjum babickie znajdowało się na drugim miejscu w swoim dekanacie, po parafii Zamch (mającej dochody 822 zł $11 \mathrm{gr})^{32}$. Podczas lustracji dokonanej w $1823 \mathrm{r}$. dochody proboszcza Babic oszacowano na 374 zł, co czyniło miejscowego duszpasterza gospodarzem najzamożniejszego beneficjum w okolicach Tarnogrodu ${ }^{33}$ i trzeciego pod tym względem w całej Ordynacji Zamojskiej34. Swoją dobrą sytuację materialną parafia w Babicach zawdzięczała jednak prawdopodobnie nie tylko czynnikowi obiektywnemu, czyli uposażeniu, lecz także swojemu wieloletniemu (1796-1842) bardzo aktywnemu proboszczowi księdzu Michałowi Bojarskiemu, który mieszkał w niej i pracował od wyświęcenia aż do śmierci ${ }^{35}$. Na początku lat czterdziestych XIX wieku ta sprawnie zarządzana, dobrze uposażona, ludna przygraniczna parafia miała stać się jednym z miejsc swoistego eksperymentu wyznaniowego, polegającego na oddolnym przeciąganiu większych grup „dusz” unickich na prawosławie.

Najpierw plan ekspansji prawosławia zaczęto wcielać w życie w Luchowie, miejscowości oddanej przez namiestnika Królestwa Polskiego (po stłumieniu „polskiej rewolucji”) w zarząd jednego z carskich generałów. Nowy rządca sprowadził do swoich dóbr - w 1840 r., pod nieobecność biskupa Szumborskiego

${ }^{27}$ W 1841 r. - 109 mórg i 144 prętów gruntów (tj. ponad 50 ha), w tym 82 m. 95 pr. pól, 17 m. 172 pr. łąki i 7 m. 15 pr. ogrodów (APL, ChKGK, sygn. 151, k. 108).

${ }^{28}$ Według wizytacji generalnej z 1839 r. Dziesięciny kopczyzna zwaney Proboszcz ze wsi Babice pobiera z gruntów przez Kogobądź posiadanych żyta rocznie po kóp czternaście, to iest z każdey ćwierci gruntu należy przez lat dwa po snopów pięć, a trzeciego roku po snopów żyta sześć, z Różańca 17 kop rocznie, 4 kopy z folwarku Jamieńszczyzna, (APL, ChKGK, sygn. 282, k. 68v), natomiast tytułem kolędy 2 razy w roku 2 bułki i 6 jajek (tamże, k. 71-71v.).

${ }^{29}$ Tego rodzaju subsydium wypłacano dziekanom - jak w wypadku Babic - oraz duszpasterzom uboższych parafii. W Babicach w 1815 r. było to 660 zł (APL, ChKGK, sygn. 147, k. 1v-2) od 1819 r. 600 zł (APL, ChKGK, sygn. 282, k. 2).

${ }^{30} \mathrm{Wg}$ protokołów oddania cerkwi w zarząd duchowieństwa prawosławnego niemal wszystkie budynki odnowiono, bądź odbudowano staraniem ks. prob. Bojarskiego (APL, ChKGK, sygn. 284, k. 55 $-55 \mathrm{v}$.$) .$

${ }^{31}$ Aczkolwiek nie jest jasne, czy było to przed „potrąceniem” podatku czy już po (APL, ChKGK, sygn. 147, k. 214v.-215). Niezależnie od tego dochody parafii były większe niż przeciętnie w dekanacie tomaszowskim - 146 zł 16 gr., lubelskim - 134 zł 10 2/3 gr. czy chełmskim - 100 zł 6 1⁄2 gr., (por. tamże, k. 206v.-218).

${ }^{32}$ APL, ChKGK, sygn. 147, k. 214v.-215.

${ }^{33}$ Dla porównania: Korchów - 220 zł, Krzeszów - 100 zł, Obsza - 66 zł (APL, ChKGK, sygn. 147, k. 214v.-215).

${ }^{34}$ Po Zamościu (par. zarządzana przez bazylianów) - 2290 zł i Szczebrzeszynie (z folwarkiem Rozłopy) - 900 zł 20 gr (tamże).

${ }^{35}$ Ks. Bojarski był również wieloletnim dziekanem tarnogrodzkim i kanonikiem kapituły katedralnej, zob. W. Kołbuk, Duchowieństwo unickie w Królestwie Polskim 1835-1875, Lublin 1992, s. 120. 
w diecezji - prawosławnego duchownego (przebywającego wcześniej w Galicji) niejakiego Ignacego Gintowta, który miał tu niezwłocznie rozpocząć tworzenie parafii. Posługując się obietnicami wyjednania u władz obniżonych podatków, uwolnienia chłopów od służby wojskowej oraz groźbami sprowadzenia wojska na opornych, skłonił kilkadziesiąt osób do porzucenia unii ${ }^{36}$. W wyniku tych ,gróźb i namów" w ciągu kilku miesięcy niemal cała wieś zadeklarowała dobrowolna zmianę wyznania. Wkrótce rozpoczęto też budowę cerkwi prawosławnej ${ }^{37}$. Nie wiadomo dokładnie w jaki sposób zbierano podpisy pod petycją ${ }^{38}$ do władz rosyjskich o utworzenie parafii.

W Babicach jako pretekst do przejmowania probostwa, beneficjum i wiernych wykorzystano zakończony w 1841 r. proces o czynsze ${ }^{39}$ między grupą chłopów z tejże wsi, a Ordynacją Zamojską, a dokładniej ich reakcję na przegraną we wszystkich instancjach. Nie mogąc się pogodzić z oddalaniem ich kolejnych pozwów i apelacji, chłopi-unici postanowili dochodzić swoich $\operatorname{praw}^{40} \mathrm{w}$ inny sposób ${ }^{41}$. Na taką przyczynę wydarzeń z przełomu lat 1841 i 1842 wskazywał kooperator (wikariusz) cerkwi babickiej - rezydujący w Różańcu - ksiądz Ignacy Horoszewicz, w liście-raporcie przesłanym 9 stycznia 1842 r. do Konsystorza Generalnego Diecezji Chełmskiej. Niepokój duchownego miała wzbudzić niewielka liczba osób, które przyszły do cerkwi w drugi dzień świąt Bożego Narodzenia (czyli dwa dni wcześniej). Zauważył też, że wielu ludzi zamiast udać się do świątyni gromadziło się w różnych miejscach wsi. Zaczął więc dowiadywać się co by byt za powód do tego ${ }^{42}$. Parafianie mieli mu powiedzieć, że już od dwóch dni (tj. od Wigilii) trwa zbieranie podpisów pod deklaracją zmiany wyznania, zainicjowane przez pozostającego bez stałego zajęcia szlachcica niejakiego Braziewicza, byłego strażnika z Tarnogrodu - świeżego zwolennika prawosławia, pomagającego w różnych sprawach księdzu Gintowtowi z Luchowa. Miał on spisać ową deklarację, w imieniu niepiśmiennych włościan i rozpocząć subskrypcya, a mając kilkunastu podpisanych odjechat zostawiwszy wiele podburzeń, obietnic i kartke do dalszych podpisów, radzac aby przez czas świąt

\footnotetext{
${ }^{36}$ Raport „O krestjanach wsi Luchowo”, za: A. Kossowski, Filip Felicjan Szumborski (1777-1751). Biskup chetmski unicki, Lublin 1937, s. 19.

${ }^{37}$ Tamże, s. 18-19; APL, Warszawski Duchowny Konsystorz Prawosławny (dalej: WDKP), sygn. 27 „Ob otkrytii w siele Luchowie prawosławnoj cerkvi i o naznaczenii że onej swiaszczennika Gintowta priczetnikom", k. nlb.

${ }^{38}$ W APL, WDKP, sygn. 27 brak takich informacji, z ,drugiej ręki” wiadomo, iż zbieranie przynajmniej części podpisów odbywało się „przy gorzałce”, zob. A. Kossowski, s. 18-19, Likowski, s. 268.

${ }^{39}$ Czynsz wprowadzono w Ordynacji Zamojskiej w 1833 r., początkowo pod nazwą okupu, w wysokości 1 zł za dzień pańszczyzny ciągłej i 15 gr. za dzień pańszczyzny pieszej. Płacono go, łącznie z innymi zobowiązaniami, w ratach kwartalnych. Osoby zalegające z czynszami mogły zostać eksmitowane z terenu Ordynacji. R. Bender, Eksmisje wtościan w Ordynacji Zamoyskiej 1843-1861, „Roczniki Humanistyczne" t. 17, 1969, z. 2, s. 102.

${ }^{40}$ Ponieważ nie zachowały się akta sprawy, nie jest też znane jej szersze tło, a źródła związane $\mathrm{z}$ administracją unicką i prawosławną przedstawiają sprzeczne opinie na ten temat, nie jest możliwe ustalenie kto mógł mieć rację w tym sporze.

${ }^{41}$ APL, ChKGK, sygn. 283, k. 40.

${ }^{42}$ Tamże, k. 40v.
} 
zebrać jak najwięcej takowych ${ }^{43}$. Natychmiast po zasięgnięciu informacji od parafian, ksiądz Horoszewicz napisał i wysłał raport do zastępcy wójta gminy Łuków. Przedstawił w nim zaistniałą sytuację i poprosił urzędnika o niezwłoczne przybycie na plebanię w Babicach w celu assystencyi w podejmowanych przez duchownego krokach duszpasterskich i administracyjnych, a także, jak można się domyślać, zapobiegania zamieszkom ${ }^{44}$. Dzień później, po przybyciu urzędnika, diak Jacenty Horosiewicz zgłosił się dobrowolnym sposobem na przesłuchanie. Zeznał, że z trzema gospodarzami pojechał do Luchowa, do tamtejszego duchownego, ale tylko raz i szybko odstąpił od dalszych wyjazdów ${ }^{45}$.

Wspomniani trzej włościanie po przegraniu sześcioletniego procesu z Ordynacją (we wszystkich Instancjach nawet u Tronu), obawiając się eksmisji szukali porady jak do swoich dawnych przywilejów wrócić by mogli ${ }^{46}$. Horosiewicz dowiedział się, iż wspomniany x. Gintowt [przy okazji jednej z takich wizyt] dowiódt im, jako sami mówia, że niczem się nie różni wyznanie grecko-rosyjskie od naszego przez okazanie im książek chórowych i zaręczyl, że powróca do praw i gruntów dawnych, jeżeli by chcieli podać na ręce jego deklaracja podpisem większej polowy wsi wsparta, iż życza sobie przyjąc religia grecko-rosyjska i mieć parocha tegoż wyznania. Chłopi mieli się na to zgodzić, a po powrocie rozgłaszać sekretnie między innych pewna nadzieję ${ }^{47}$.

Kilka godzin później, po przesłuchaniu diaka i niedzielnym nabożeństwie, ksiądz Horoszewicz miał się przekonać, że grupa zwiedzionych jest kilkakrotnie większa niż dzień wcześniej. Zbuntowani parafianie nie chcieli słuchać odezwy księdza $w$ przedmiocie wyprowadzania z błędu [...] okazania mylności obietnic jakoteż utwierdzenia $w$ wierze katolickiej i zaczęli wychodzić z cerkwi. Duchowny poszedł za nimi, prosząc by zgromadzili się wokół niego, ale wielu nie stuchało, nie zatrzymując się i rozchodząc do domów. Pozostali zaczęli krzyczeć: Tonący brzytwy się chwyta! i Żydem zostanę, abym miat sposób do życia!, nie zważając ani na argumenty księdza, ani na obecność przedstawiciela władz ${ }^{48}$. Sytuację w parafii pogarszała poważna choroba pozostającego na plebani księdza Bojarskiego, który nie był w stanie (również dosłownie) przeciwstawić się grożącym zamieszkom. Proboszcz mógł tylko upoważnić swojego zastępcę do spisania i wysłania raportu do Chełma, co ksiądz Horoszewicz uczynił ${ }^{49}$.

${ }^{43}$ Tamże, k. 40-40v. Według akt rosyjskich związanych z przejmowaniem parafii babickiej przez prawosławnych duchownych gospodarze mieli poprosić Faustyna Braziewicza o sporządzenie spisu tych (APL, ChKGK, sygn 284, k. 2-3), którzy chcą powrócić do pradziadowskiego obrządku (czyli prawosławia) i mieć własną prawosławną parafię z duchownym oraz osobnej deklaracji wierności wobec obrządku grecko-rosyjskiego (APL, ChKGK, k. 4-5). Na pierwszej liście widnieje 27 osób, na drugiej już 102 (tylko mężczyzn) z rodzin m.in. Pirogów, Rahuliczów, Dubiców, Parnaków, Senyków, Fyków i Szłodów.

${ }^{44}$ Tamże, k. 40v.

45 Tamże.

46 Tamże, k. 40.

47 Tamże.

48 Tamże, k. 55.

49 Tamże. 
Pismo to z kancelarii konsystorza trafiło do rąk biskupa Szumborskiego, który po zapoznaniu się z nim wystosował do administracji dóbr Ordynacji Zamojskiej prośbę o zaradcze środki dla uchylenia złego we wsi Babice ${ }^{50}$. Hierarcha podkreślał, że ani jego list pasterski skierowany do tamtejszych włościan dla wyprowadzenia jednych z błędu, a drugich utwierdzenia w wierze katolickiej, ani nauki xa Ignacego Horoszewicza [...] dawane obłakanym nie przyniosa skutku, jeżeli nie zostaną wsparte $^{51}$ przez samego JW. Dziedzica i Kollatora. W związku z tym biskup oczekiwał, iż Szanowna Administracja zaleci Zastepcy Wójta Gminy Tamecznej, aby na te wioske, obecnie podburzona, miat baczne oko, nie dopuszczat schadzek tak po domach jako też austeriach $i$ wzbraniat przystępu poduszcicielom zwłaszcza, iż to wypływa z przepisów rzadowych i policyjnych ${ }^{52}$. Ponadto, zdaniem biskupa, Ordynacja - dla przekonania [...] ubogiej i ciemnej prostoty, nie mogacej zgłębić Wysokich tajemnic Wiary, zapewniających szczęśliwość wieczna, karmiacych się tylko tudzaca doczesnościa, która im podżegacze obiecuja - mogłaby zwolnić chłopów $z$ należacej się opłaty lub té̇ rozłożyć [ją] na czas dłuższy, dla przekonania ich $i$ utwierdzenia, że bez obrazy sumienia $w$ potrzebie moga znaleźć nad soba politowanie $^{53}$. Dla uwiarygodnienia swojej prośby biskup dołączył do niej odpis raportu księdza Horoszewicza ${ }^{54}$.

Chełmski hierarcha napisał również, wspomniany wcześniej, list pasterski skierowany do parafian wsi Babice ${ }^{55}$. Powołując się na zapisaną w Piśmie Św. troskę o powierzoną duchową ,trzodę”, apelował do włościan, którzy dobro doczesne tego świata przedkładają nad swoje zbawienie, pragnąc oddalić się z zagrody i owczarni, porzucając wyznanie, w którym urodzili się, wychowali $i$ wyrośli na syny Boże. Dlatego też otrzymana wiadomość o złych chęciach $i$ zamiarach tych, który chcą zdradzić ojczyste wyznanie [...] napetniła [go] sroga boleścia i smutkiem ${ }^{56}$. Zamiarom buntowników hierarcha przeciwstawił postawę przodków, pochowanych na miejscowym cmentarzu, którzy nigdy nie pomyśleli nawet o porzuceniu swojego wyznania $^{57}$. Biskup pytał retorycznie: Brakowało Wam i dziatkom Waszym na postudze duchownej kiedy w tej naszej owczarni? Czy łaknęliście i nie nakarmiono was CiaŁem najdroższym Chrystusowym i słowem Bożym? [...] Czyliż odmówiono postugi waszym chorym [...] czy zmarli wasi [...] nie znaleźli przyzwoitego pogrzebienia?58; przestrzegał przed gniewem Bożym, który spada na ufających ludziom zastawiaja-

${ }^{50}$ Tamże, k.41-41v.

${ }^{51}$ Aby tem mocniej działały na umyst i serce tak rozpaczajacych, jako też chwiejacych się poduszczenia trafiajacego w ich przekonania włościan, (tamże, k. 41).

${ }^{52}$ Tamże.

53 Tamże, k. 41 v.

54 Wspomina o tym na początku listu (tamże, k. 41).

55 Datowany na 8/20 stycznia 1842 , nie wiadomo kiedy odczytany.

${ }^{56}$ APL, ChKGK, sygn. 283, k. 42.

${ }^{57}$ Mogłoż to kiedy paść na myśl Waszym ojcom, Waszym przodkom iżby się odstapili tego wyznania wiary Ś. W którym zrodziliście się, wychowali i porzysięgli Bogu na chrzcie S. wytrwać do zgonu Waszego! (tamże, k. 42).

58 Tamże, k. 42v. 
cym sidta, bowiem przyrzekaja oni to, czego nie sq w stanie dotrzymać [...] żartuja $z$ Waszj prostoty. obiecuja wam urojonq wolność $!^{59}$ - tym samym przekonywał wahających się, że zmiana wyznania byłaby nie tylko zdradą Boga, lecz również $\mathrm{Ce}$ sarza i Króla, jednakowo szanującego wszystkie wyznania w swoim państwie oraz wypowiedzeniem wierności wobec dziedzica, w tym wypadku hrabiego ordynata Zamoyskiego ${ }^{60}$. Biskup przekonywał też, że dziedzic daleko więcej może pozyskać względów [...] i pewniejsze taski u władcy niż ci, którzy obietnicami [...] tudza. List zakończył apelem: Zapozywam ja was na Sąd Boski! Zaklinam na wiarę Ojców waszych! Na zbawienie Wasze! Bądźcie stałemi, bąźcie wiernemi Bogu, Cesarzowi i ulegli Panom Waszym [...] od tego zawisto i szczęście wasze tak wieczne, jak i doczesne. Postuchajcie mnie [...] Pasterza waszego, zbawienia dusz Waszych pragnacego [...] starca nad grobem stojacego ${ }^{61}$.

Prawdopodobnie słowa te nie spotkały się z odzewem i nie skłoniły babickich parafian do zmiany ich postępowania. W następnym raporcie ${ }^{62}$, tym razem adresowanym bezpośrednio do biskupa, ksiądz Horoszewicz ubolewał nad postępem zła, które czyhajace jak zwierz wsi chciwy [...] nieostrożnych przez podstępne obietnice i podmowy nieprzyjazny nam duchowny zapalit. Podzielił się też obawą czy podoła obowiązkowi przekonania obłąkanych kierując się tylko swoim niewielkim doświadczeniem i poradą chorującego proboszcza. Jednocześnie zadeklarował dalsze przekonywanie parafian do pozostawania przy swojej wierze przez ciągłe, nawet natrętne, pouczanie i przemawianie do ludzi w cerkwi lub w ich domach. Miał też zamiar uprosić chłopów aby znowu jechali do Luchowa i [...] tam już z nimi bedac, przy nich dowieść, iż co tamten obiecuje jest fatsz, oszukanie. Wyraził także nadzieję na szybkie rozwiązanie przez ordynację sprawy czynszów, gdyż przy upowszechnionym pijaństwie i złodziejstwie chłopi nie byliby w stanie regularnie płacić podwyższonych składek, co mogłoby stać się początkiem buntu - przeciw władzy duchownej i świeckiej - na całym obszarze Ordynacji ${ }^{63}$.

Trzy dni później ksiądz Horoszewicz pisemnie zrelacjonował biskupowi śledztwo przeprowadzone przez komisarza obwodu zamojskiego czterech chłopów, którym prawosławny duchowny obiecał uwolnienie od ciężarów finansowych pod warunkiem zmiany przez nich wyznania. Na jego polecenie miano zebrać 140 podpisów pod deklaracją przejścia na obrzadek grecko-rosyjski. Po kolejnych przesłuchaniach okazało się jednak, że wiele osób nie było obecnych przy zapisach, a ich nazwiska podyktowali inni. Takich pozornie zapisanych - relacjonował ksiądz Horoszewicz - było przynajmniej kilkunastu, jednakże, z powodu lęku przed zemstą sąsiadów, oprócz kilku komorników [...] jawnie nikt nie zadeklarowat się być statym ${ }^{64}$.

\footnotetext{
59 Tamże.

${ }^{60}$ Tamże, k. 42v.-43.

61 Tamże, k. 43.

${ }^{62}$ Datowanym na 9/21 stycznia $1842 \mathrm{r}$.

63 Tamże.

64 Tamże, k. 47-47v.
} 
Natomiast inni włościanie słuchają nauk z zimna obojętnościa a nawet uśmiechem świadczącym o pustocie i mocnem namówieniu ${ }^{65}$.

Dzieląc czas między obowiązki związane z zastępowaniem proboszcza w Babicach i posługą wikariusza w Różańcu ksiądz Horoszewicz dowiedział się, że ks. Gintowt obiecał różanieckich gospodarzy od mesznego kościołowi tarnogrodzkiemu przez parafian g. u. oddawanego uwolnić pod wiadomym warunkiem ${ }^{66}$.

Tymczasem władze rosyjskie, reprezentowane przez komisarza obwodu krasnostawskiego, delegowanego przez gubernatora lubelskiego ${ }^{67}$, postanowiły przekonać się „naocznie” o liczbie osób deklarujących zamiar zmiany obrządku oraz o istotnych powodach $i$ chęciach podjęcia tego kroku. Komisarz po zebraniu się znacznej liczby włościan odczytał głośno liste przy deklaracji przez nich podana ${ }^{68}$. Następnie delegat gubernatora zapytał zgromadzonych: „Czyli życzycie sobie mieć księdza grecko-rosyjskiego i przyjąć to wyznanie?”, na co [chłopi] odpowiedzieli „,̇yczymy”, a spytani „Czyli macie jakie krzywdy od Ordynacji Zamoyskiej i może z tych powodów chęci wasze objawienie?” jednogłośnie odpowiedzieli: „, Nie mamy $i$ dla tego tylko chcemy tego, że nam się taż religia podobała.” Ksiądz Horoszewicz ubolewał nad tym, że nie został wezwany na to zebranie, gdyż miał zamiar oprotestować deklaracje chłopów - znacznie lub zupełnie sprzeczne z tym, co usłyszał dzień wcześniej pod przysięgą ${ }^{69}$.

Dokładniejsze wyobrażenie o babickich zdarzeniach z przełomu 1841 i 1842 r., dają zeznania wspomnianego wcześniej diaka Jacentego Horosiewicza złożone przed biskupem Szumborskim, który przejęty otrzymywanymi raportami o niepokojach w Babicach, osobiście ${ }^{70}$ przybył do podburzonej wsi $i^{71}$. Diak - zapytany o istotnej przyczynie zaszłych świeżo $w$ tutejszej parafii niespokojności i co by takowe

${ }^{65}$ Tamże, k. 47v.

${ }^{66} \mathrm{~W}$ związku z tym postanowił podjąć odpowiednie kroki w pewnej nadziei, iż wkrótce zaspokoić się dadzą przez łatwe zniesienie mesznego, bez żadnego tytułu na nich włożonego przez ordynacją po regulacji gruntu w 1822 r. (tamże, k. 7v). Nie wiadomo czy duchowny rzeczywiście podjął te starania i jaki był ich, ewentualny efekt.

${ }^{67}$ Babice należały do okręgu zamojskiego, prawdopodobnie władzom delegującym ,neutralnego” urzędnika zależało na pozorach bezstronności.

${ }^{68}$ Odpis tej listy ks. Horoszewicz przesłał biskupowi, wymienionych jest tam 111 nazwisk deklarujacych się na obrzadek gr. ros. oraz 34 gospodarzy niezdecydowanych - lepiej się majacych $i$ spokojnych. Przy nazwiskach pierwszej części deklaracji ks. Horoszewicz umieścił swoje adnotacje dotyczące osób zmarłych 4 i 5 lat wcześniej (2 osoby) bądź odsiadujących wyrok w więzieniu (2 osoby), a mimo to zapisanych. Na liście znalazło się oprócz tego 14 osób zapisanych dwu- lub trzykrotnie, jeden gospodarz obrządku łacińskiego, jeden zbiegły ze wsi dwa lata wcześniej, a także 11 osób, które nie były obecne przy tworzeniu listy, a zapisał je ktoś inny. W pierwszej części listy pojawiają się najczęściej nazwiska Rybałt, Fyk, Krawiec, Korżak, Szłod, Szłodzik, Kaczkowski, Piróg, Seneyko, Parnak, Mociak, Dubica i Rahulicz - byli to przedstawiciele najliczniejszych rodzin we wsi. Przy żadnej osobie nie ma adnotacji ,z rodziną”, „z żoną i dziećmi”, co może, choć nie musi świadczyć, że bliscy buntowników pozostali przy swoim wyznaniu (APL, ChKGK, sygn. 283, k. 49 -49a)

${ }^{69}$ APL, ChKGK, sygn. 283, k. 48

${ }^{70} \mathrm{~W}$ towarzystwie sufragana - ks. bp. Jan Teraszkiewicza i ks. Antoniego Hryniewieckiego oficjała diecezji.

7124 stycznia/5 lutego 1842 r. (APL, ChKGK, sygn. 27, k. 12; APL, ChKGK, sygn. 283, k. 50). 
sprawito $^{72}$ - opowiedział o niepokojach wśród gospodarzy związanych z przegranym procesem o czynsze. Nie uwierzyli oni w zapewnienia Ordynacji o rozłożeniu opłat na raty ${ }^{73}$. Dlatego też dwaj z nich - Konrad Rybałt i Jerzy Fyk - przybyli 24 grudnia, w Wigilię Bożego Narodzenia obrządku łacińskiego ${ }^{74}$, do domu diaka, żądając wydania im przechowywanych na plebanii praw na zasadzie których prowadzit sie proces z Ordynacja ${ }^{75}$. Na pytanie diaka: Co myślicie z temi prawami jeszcze zrobić, mieli odpowiedzieć: Oto myślimy udać się po rade jeszcze do Luchowa. Podczas krótkiej wymiany zdań Horosiewicz dowiedział się, że z wymienioną dwójką gospodarzy ma jechać także Teodor Dubica. Wówczas postanowił pojechać z nimi ${ }^{76}$ Następnego dnia, zgodnie z tą umową, wszyscy czterej, jeszcze przed świtem, udali się do luchowskiego kapłana ${ }^{77}$. Ten zaś, wysłuchawszy ich, miał powiedzieć: $o$ nic bardziej starać się nie trzeba, jak o to jedynie abyście dopraszali Wysokiego Krajowego Rzadu iżby wam przysłał takiego księdza jak ja, a ten potrafi się za wami w urzędzie wstawić $i$ wyjednać dla was wszystko, wiecie wszakże, że teraz jest Rząd Rossyjski, który dla swoich niczego nie odmawia. Później pokazał im cerkiew i zaprosił na nieszpory, oni jednak pojechali do domów, a krótki pobyt w Luchowie nie pociagną za soba żadnego skutku ${ }^{78}$. Półtora tygodnia później Dubica, Rybałt i Fyk ponownie pojawili się na plebanii. Przynieśli ze sobą list napisany w Dzikowie, w Galicji, adresowany do księdza Gintowta. Mieli zamiar dostarczyć pismo luchowskiemu kapłanowi. Zdenerwowany ich najściem diak miał im powiedzieć: róbcie sobie co chcecie, ja o niczem nie chce wiedzieć! !79. Dwa dni później, w wigilię obrzadku greckiego do wsi przyjechał były strażnik Braziewicz $i$ w karczmie zabawiat się z zebranymi mieszkańcami Babic i jak sami obecni zebrani oświadczaja, udawszy się z niemi po zabawie do Jerzego Fyka tam odbierat podpisy tych wszystkich, którzyby oświadczyli chęć przejścia na obrzadek grecko-rossyjski podpiwszy sobie pierwej, a dnia trzeciego potem spisywat ochotników do odmiany wyznania Daniel Korżak, syn Bazylego Korżaka maiacy lat około $14 t u^{80}$. Później Rybalt Kondrat i inni chwalili się, jako ksiadz Gintowt obiecat im wyjednać uwolnienie od niektórych podatków i inne swobody, tudzież, że dostana po złotych polskich sto, jeżeli się zdeklaruja i zdecyduja na zmianę wyznania ${ }^{81}$. Słowa Jacentego Horosiewicza potwierdziło kilku wezwanych przedstawicieli gromady ${ }^{82}$.

\footnotetext{
72 APL, ChKGK, sygn. 283, k. 50.

73 Tamże, k. 50v.

7412 grudnia w kalendarzu juliańskim.

${ }^{75}$ APL, ChKGK, sygn. 283, k. 51.

76 Tamże.

77 Tamże.

78 Tamże.

${ }^{79}$ Później diak dowiedział się, że z listem tym chodzili do Luchowa Jerzy Fyk i Kazimierz Saduń (APL, ChKGK, sygn. 283, k. 51).

${ }^{80}$ Tamże, k.51v.

${ }^{81}$ Tamże. W tych zeznaniach jedyny raz pojawia się „wątek korupcyjny”.

82 Tamże.
} 
Krótki pobyt biskupa Szumborskiego w Babicach przebiegł w atmosferze niepokoju, prowokowanego przez [niektórych] włościan - o czym wspominał, zarówno w cytowanym protokole zeznań diaka, jak i w późniejszym liście do prawosławnego

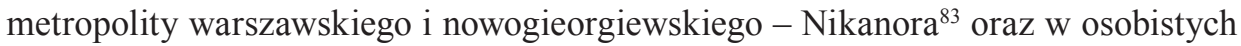
notatkach z czasu żałoby po śmierci księdza Bojarskiego ${ }^{84}$. Nie jest przy tym do końca jasne czy wiadomość o odejściu proboszcza Babic zastała biskupa w Chełmie, co sugeruje jego dziennik ${ }^{85}$, czy też w drodze do zbuntowanej wsi, o czym może świadczyć początek protokołu ${ }^{86}$. Nie jest też jasne czy duchowny bardzo długo i obłożnie chorował, a jego zgon przyspieszyły wiadomości o postępowaniu parafian, czy też sami włościanie w jakiś bezpośredni sposób przyczynili się do jego zejścia. Niczego nie wyjaśniają tu słowa biskupa, o tym, że widząc ciało zmarłego księdza powziąt bolesne a niewatpliwe przekonanie, że tenże zgasty w Bogu kapłan padt ofiara zaszłych $w$ powierzonej sobie parafii niespokojności ${ }^{87}$. Odprawiwszy mu pogrzeb, z grupą towarzyszących księży dwóch obrządków, biskup Szumborski udał się na plebanię, gdzie przebywał do wieczora. Następnego dnia odprawił nabożeństwo w cerkwi babickiej z nauka do parafian zachęcajac ich, aby się trzymali wiary $i$ wyznania katolickiego, ${ }^{88}$ a 7 lutego pojechał z takąż nauka do Tarnogrodu $u^{89}$.

We wspomnianym liście do metropolity prawosławnego biskup Szumborski dokładnie zrelacjonował wydarzenia w Babicach (miejscu pełnym niepowodzeń $i$ występków), w tym swój pobyt w tej miejscowości. Chełmski hierarcha pisał także, iż dowiedział się, że ksiądz Bojarski schodzac z tego świata wyrzekat, że przyczyna i przyspieszeniem śmierci jego byty pobuntowane umysty jego parafian ${ }^{90}$. Potwierdziło to, według biskupa, przeprowadzone na miejscu śledztwo, które ujawniło nie tylko - w celu skłonienia do porzucenia wiary - składanie chłopom obietnic umorzenia długów i podatków, lecz również szantaż, straszenie sprowadzeniem wojska

${ }^{83}$ Z 7/19 lutego 1842 r. (APL, ChKGK, sygn. 283, k. 60-61v).

${ }^{84}$ Z dziennika biskupa Szumborskiego: Z powodu śmierci ś. p. Michała Bojarskiego dziekana tarnogrodzkiego, kanonika chetmskiego, proboszcza Babic, jako też z okoliczności rozruchów religijnych $w$ tym dekanacie rozszerzajacych się i na jedność święta z Kościołem rzymskim powstajacych, przez $x$. Gintofta kaptana nieprzyjaciela unii św. podżeganych, a przez gubernatora lubelskiego Albertowa protegowanych [...] wyjechałem dnia 3 lutego $w$ dekanat tarnogrodzki (APL, ChKGK, sygn. 27, k. 12)

${ }^{85}$ Tamże.

${ }^{86}$ Biskup żałował, że nie mógł spotkać się z tarnogrodzkim dziekanem, którego zastał już na katafalku (APL, ChKGK, sygn. 283, k. 50).

${ }^{87}$ APL, ChKGK, sygn. 283, k. 50. W późniejszych, na poły publicystycznych opracowaniach ks. E. Likowskiego, Dzieje kościoła unickiego, s. 368 i J.P. Bojarskiego, Czasy Nerona, s. 23, znajdujemy sugestię, u P. Bojarskiego, graniczącą z pewnością, że ksiądz M. Bojarski polegt uderzony kamieniem w głowę, gdy przemawiał do zbuntowanych parafian.

${ }^{88} 6$ lutego, w obecności biskupa, sporządzono listę osób deklarujących pozostanie przy unii. Znajduje się na niej 36 nazwisk (w tym 22 osoby z rodzinami). Większość z nich to gospodarze i wdowy po gospodarzach, prawdopodobnie jest też na niej kilku komorników. Cztery osoby podpisały się własnoręcznie - diak Jacenty Horosiewicz i troje służących na plebanii (APL, ChKGK, sygn. 283, k. 107).

${ }^{89}$ APL, ChKGK, sygn. 27, k. 12.

90 Tamże, s. 60. 
i zrujnowaniem i z blotem zmieszaniem wsi ${ }^{91}$. Smutek i zgorszenie unickiego hierarchy zwiększał fakt zbierania podpisów w karczmie przy gorzałce, trunku łakomym dla chlopstwa, a także to, że inicjatorami, czy wręcz prowodyrami buntu byli przedstawiciele grupy pijaków, lotrów i kryminalistów, na czele z Teodorem Dubicą czlowiekiem burzliwego charakteru [...] buntownikiem i pijakiem, który już wcześniej miał zatargi z Ordynacją Zamojską, a tylko dzięki osobistemu wstawiennictwu zmarłego proboszcza uniknął wyrzucenia ze wsi i gospodarstwa ${ }^{92}$. Jedynie kobiety (wszystkie, jak pisał biskup) nie wstapity w ślady swoich mężów [...] i zostaty przy rodowitem obrzadku. Niestety, z tego powodu powstaty niezgody domowe, zgorszenia dzieci i domowników ${ }^{93}$. Hierarcha pisał też, że widział na własne oczy włościan podzielonych na bandy, organizujących pijatyki i przechwalających się spodziewanymi korzyściami ze zmiany wyznania, grożących tym, którzy nie chcieli się do nich przyłączyćc ${ }^{4}$. Jednak to nie wzrastająca demoralizacja chłopów i groźba otwartego buntu najmocniej wstrząsnęła biskupem, lecz zachowanie księdza Gintowta. Przybył on na plebanię babicką w dniu pogrzebu księdza Bojarskiego niby z oświadczeniem grzeczności dla biskupa Szumborskiego $i$ w gronie kilkunastu kapłanów obojga obrzqdków zjadtszy objat [...] tak śmiat się [do biskupa] odezwać: ,,Ponieważ wielka część parafian babickich przeszła już do wyznania mojego, a miejscowy paroch zszedt z tego świata, wzywam przeto imieniem Rzadu, aby klucze od Cerkwi parafii babickiej oddane mi byty"95. Takowa nierozmyślna Jego odezwa - napisał biskup - tzy z oczów moich wycisnęta, a będąc w duszy i sumieniu mojem przekonanym, że wyrazy Imieniem Rzq̨du wyrzeczone przez niego znieważyly tenże Rzad, obróciwszy się do kapłanów mnie otaczających, protestowatem się Bogiem, że póki żyć będę sumienia nie zdradzę mojego, na ta nieprawdę i obstawać nie przestane przy obowiązach, które mi Sam Bóg i Najjaśniejszy nadat Cesarz ${ }^{96}$. W dalszej części listu biskup Szumborski pytał prawosławnego hierarchę czy dopuszczalna jest tak prowadzona propaganda jednego wyznania kosztem innych, gdyż - według wszelkiej wiedzy i wiary ${ }^{97}$ - dotąd w Cesarstwie Rosyjskim szanowano wszelkie religie, nawet wyznania bałamutne różnych ludów w nim zamieszkujących ${ }^{98}$, szanowano także posłusznych i prawowiernych kapłanów diecezji chełmskiej, którzy w czasie

91 Tamże.

92 Tamże, k. 60. Wśród zapisanych znaleźli się m.in. (zaocznie) dwaj odsiadujących wyrok za kradzieże, a siedemdziesięcioletnia matka Dubicy zeznała, że syn rękę swą bezbożna podnosi na nia (APL, ChKGK, sygn. 283, k. 60-60v).

93 Tamże, k. 60v.

94 Tamże.

95 Tamże.

96 Tamże. Wydarzenie to opisał również, w tajnym raporcie do gubernatora lubelskiego, sekretarz obwodu zamojskiego, cytując (po polsku) słowa biskupa. (APL, ChKGK, sygn. 284, k. 17v.)

${ }^{97}$ Nie wiadomo czy biskup miał tak małą wiedzę na temat sytuacji (byłych) unitów za Bugiem, czy dość naiwnie długo wierzył w dobre intencje władz państwowych, czy też powodowała nim zwykła grzeczność wobec innego hierarchy.

${ }_{98}$ Biskup zestawił ze sobą przykłady plemion syberyjskich, Kirgizów, starowierców i wiary luterskiej, którym prawo państwowe gwarantowało wolność wyznania (APL, ChKGK, sygn. 283, k. 61v). 
rewolucji 1830 r. za wierność i przywiązanie do Tronu mieli cierpieć prześladowanie $i$ więzienie od rewolucjonistów ${ }^{99}$. Do argumentu lojalności i zaniepokojenia tym co usłyszał i zobaczył biskup Szumborski odwoływał się również pisząc, iż Wysoka Cywilizacja i Oświata [...] rosyjskiego narodu potężnego wiele ucierpieć może z postępowań ludzi, nieumiejących szanować publicznej opinii, które wiek 19ty nie wahaja się równać $z$ wiekami dawno upłynionemi prześladowań religijnych ${ }^{100}$. W celu wyjaśnienia wszystkich wątpliwości zaistniałych wokół babickiej cerkwi, a także zapewnienia o lojalności, biskup pragnął spotkać się z namiestnikiem Królestwa Polskiego, i - jak pisał - upaść do jego nóg ${ }^{101}$. Do tego spotkania, jak miało się okazać, doszło dopiero po kilkunastu miesiącach, kiedy nikt z rządu ani stuchać nie chciał o udzieleniu pozwolenia powrotu do unii. Biskupowi oświadczono wówczas, że co się stanie, odstać się nie może, a prawosławia opuszczać $i$ do unii wracać nie wolno ${ }^{102}$.

W czasie gdy unicki hierarcha pisał list (na który miał nie otrzymać odpowiedzi) do Warszawy, administratorem parafii Babice był już ksiądz Horoszewicz. Biskup przekazując mu - oficjalną pisemną nominacją ${ }^{103}$ - pieczę nad parafią udzielił nowo installowanemu kilku poleceń i wskazówek. Przede wszystkim: ksiądz Horoszeiwcz powinien stale przypominać chłopom o ich obowiązkach i posłuszeństwie względem cara i dziedzica ostrzegając, że podniesienie przeciw temu rokoszu będzie poskromione z pomoca rządu; powinien też piętnować praktyki i słowa księdza Gintowta, w tym głoszone przez niego wyrażenie się o lepszości religii wyznania grecko-rosyjskiego ${ }^{104}$ oraz jego niezgodne z powołaniem postepy, z naruszeniem publicznej spokojności i starać się by nie uszły one bezkarnie. Jednakże nowemu administratorowi nie wolno odmówić komukolwiek postugi duchownej. Nie wolno też oddawać nikomu kluczy cerkiewnych ${ }^{105}$.

Biskup Szumborski skierował również do komisarza obwodu zamojskiego prośbę o przesłanie odpisów dokumentów dochodzenia w sprawie Babic ${ }^{106}$, z których napływały tymczasem kolejne niepokojące wieści. Ksiądz Horoszewicz otrzymał, na początku lutego 1841 roku $^{107}$, pisemny zakaz księdza Gintowta (kurtuazyjnie nazwany uwiadomieniem) pełnienia posługi wśród zmieniających

\footnotetext{
99 APL, ChKGK, sygn.283, k. 61v.. Nie wiadomo na jakich przesłankach, poza deklarowaną osobistą lojalnością biskupa, opierał się ten fragment listu.

100 Tamże, k. 61.

101 Tamże.

102 E. Likowski, Dzieje Kościoła unickiego, s. 368.

10315 II 1842 r.(wg nowego stylu)

${ }^{104}$ Cesarz chce tylko wierności wobec tronu. W czem nas raczył zapewnić Statutem Organicznym, który wielebność Twoja znajdziesz w aktach zmarłego śp. parocha Babic (APL, ChKGK, sygn. 283, k. 53).

105 Tamże, k.53-53v.

${ }^{106}$ Gdzie zbuntowani w większej części włościanie, wśród zalewania się gorącym trunkiem dopuszczają się różnych bezprawiów, dla urojonych pretensji do JW. Hrabiego Ordynata [...] wyrzekając się swego wyznania (APL, ChKGK, sygn. 283, k. 55).

${ }^{107}$ Czyli 27 stycznia według kalendarza juliańskiego.
} 
wyznanie $^{108}$, na co (równie grzecznie) odpowiedział, że nie może odstapić od tego, co nakazuje mu prawo i obowiązek, tym bardziej, że wiele osób wciągnięto na wiadoma listę [...] pod osobistą nieobecność. Wyraził też nadzieję, że liczni mamieni obietnicami i straszeni włościanie, mając stałą opiekę swojego duszpasterza, powrócą do rodzimego wyznania ${ }^{109}$. Dzięki temu nie powtórzą się, uważał administrator, gorszące i nieprzyjemne sytuacje sporów o udzielanie ślubów czy grzebanie umarłych $^{110}$.

Również władze świeckie wystosowały pismo ${ }^{111}$ do ks. Horoszewicza w sprawie zaprzestania jego praktyk. Tym razem jednak chodziło o - rzekome - czynienie obelg włościanom wsi Babic. Dlatego też, ostrzegał komisarz obwodu zamojskiego, ksiądz powinien dostosować się do poleceń burmistrza Tarnogrodu i, wraz z zastępca wójta Łukowy, zaprzestać nachodzenia ludzi w domach. W przeciwnym wypadku, przy jakimkolwiek najmniejszym uchybieniu czy krzyku ze swojej strony, unicki duchowny może zostać pociągnięty do odpowiedzialności karnej ${ }^{112}$.

Biskup w odpowiedzi na napływające z Babic, niemal rozpaczliwe pisma, wystosował kolejną prośbę do Ordynacji Zamojskiej, tym razem do jej plenipotenta, o podjęcie jakiegokolwiek działania mogącego powstrzymać dalszą demoralizację chłopów, albo wpłynąć na zmianę postępowania władz państwowych, które zamiast przeciwko rokoszanom występują przeciw gminie i probostwu unickiemu ${ }^{113}$.

O tym, że ksiądz Gintowt mógł, mając co najmniej ciche poparcie władz administracyjnych Tarnogrodu, Luchowa i obwodu zamojskiego oraz własnych duchownych zwierzchników, czuć się w Babicach coraz pewniej ${ }^{114}$, świadczą kolejne raporty księdza Horoszewicza do biskupa Szumborskiego ${ }^{115}$. Prawosławny duchowny, mając coraz bardziej widoczne poparcie części wsi (oficjalnie deklarującej trzymanie się razem), wykorzystując skłócenie rodzin, ciągłe wyśmiewanie lub zastraszanie wahających się oraz wspominane wcześniej obietnice, zaczął mieszać się w uprawnienia

${ }^{108}$ Powoływał się przy tym na reskrypt (rozporządzenie) w tej sprawie wydany 19/31 I $1842 \mathrm{r}$. (zob. APL, ChKGK, sygn. 283, k. 57-57v).

109 Tamże, k. 56-56v.

${ }^{110}$ Niewiele brakowało by doszło do takiej sytuacji. Pewna kobieta, pod bytność Jaśnie wielmośnego Pasterza była opatrzona sakr. ŚŚ, zmarła tegoż dnia-relacjonował ks. Horoszewicz - i już przez Xa Gintowta miała być chowana, ale udałem się do niego z dowodami, które wyrozumiawszy pretensji do chowania zaniechat (tamże, k. 56v).

11121 stycznia/5 lutego $1842 \mathrm{r}$.

112 APL, ChKGK, sygn. 283, k. 58-58v.

${ }^{113}$ Tamże, k. 59-59v. Znamienne, że biskup napisał o urojonych i jakoby doznanych krzywdach włościan, co może świadczyć o deklaracji, nie wiadomo, czy spełnionej, obniżenia czynszów (tamże, k. 59v).

114 Początkowo rozważano przyłączenie Babic do Luchowa, o czym może świadczyć pismo konsystorza (14/26 II 1842) do ks. Gintowta z pytaniami o odległość między miejscowościami, liczbę wiernych, stan techniczny cerkwi i uposażenie probostwa (APL, ChKGK, sygn. 284, k. 6-6v. Po otrzymaniu odpowiedzi o dużej odległości (12 wiorst) między Babicami i Luchowem oraz wystarczającej liczbie osób wschodniego obrządku w Babicach i Różańcu $(145+65)$, a także informacji o wysokim dochodzie (824 zł) zrezygnowano z tego (tamże, k. 7v.-8).

115 Z lutego i marca 1842 r. 
duchownego unickiego sprawując posługę bez jego wiedzy i zgody ${ }^{116}$, nie reagując na najuprzejmiejsze prośby ze strony administratora - tak ustne, jak i pisemne - aby przestał to czynić ${ }^{117}$. Posług tych udzielał ksiądz Gintowt bezpłatnie, wbijajac we włościan przekonanie, że opłaty nazywane ofiarą stuły są wymysłem duchownego unickiego i robieniem trudności ${ }^{118}$. Łamiąc postanowienia Statutu Organicznego oraz prawa kanonicznego duchowny z Luchowa udzielił dwóm wdowcom ślubów bez zapowiedzi [...] bez metryki, bez przekonania się o chrzcie i letniości panien równie o śmierci pierwszych żon wdowców ${ }^{119}$. Innym razem pochował małoletniego Marcina Daćkę i Mariannę z Sajów Zawitaszową po upływie zaledwie 7 i 10 godzin od ich zgonów ${ }^{120}$. Zmarła kobieta została pochowana przez księdza Gintowta wbrew jej woli, wyrażonej w obecności brata, matki i innych świadków, w czasie swojego pobytu u bliskich w Różańcu ${ }^{121}$. Na krótko przed śmiercią wysłała brata do księdza Horoszewicza, aby ten udzielił jej ostatnich sakramentów. Jej bliscy mówili później, że wielokrotnie skarżyła się im na wciągnięcie jej na wiadoma listę bez jej wiedzy, tylko dlatego, że jej mąż odmienił wyznanie $e^{122}$. Administrator przybył do Babic już w trakcie pogrzebu odprawianego przez księdza Gintowta i zawezwat go do przerwania ceremonii. Gdy to nie przyniosło efektu ksiądz Horoszewicz zaczął mu cytować z pamięci, a później również czytać, artykuły Statutu Organicznego zapewniające wolność wyznania w Królestwie Polskim. Gintowt miał na to odpowiedzieć: Mąż chce, więc ja pochowam. W tej sytuacji ksiądz Horoszewicz musiał ustąpić. Kiedy wychodził z cmentarza, dogonił go Aleksy Saja, brat zmarłej i obiecał, że sam opłaci koszty pogrzebu ${ }^{123}$. Innego dnia JX Gintowt byt przyczyna nieporzadku w cerkwi, bo skłonit włościan aby ofiary, które [...] zwykli przynosić przed msza trzymali ukryte, aby po Mszy Św. i procesji na cmentarz mógł ofiary sobie zabrać ${ }^{124}$. W tym celu wysłał swojego diaka i kilku chłopów pod furty, by namawiali ludzi do zatrzymywania datków do końca nabożeństwa ${ }^{125}$. Widząc to ksiądz Horoszewicz zaczął przekonywać włościan, że sprawując ofiarę za przodków ich prawowiernych [...] ma stuszne prawo oczekiwać datków po jej zakończeniu, gdyż zastępuje tu proboszcza otrzymującego nagrodę, a nie wikariusza modlącego się

116 APL, ChKGK, sygn. 283, k. 64v.-65.

117 Tamże, k. 65v -65.

118 Tamże, k. 65-65v.

119 Tamże, k. 65v -66.

120 Tamże, k.66.

${ }^{121}$ Zeznała, iż pragnie być wierna rodowitej Cerkwi i zapisana na listę tej wierze przychylna (APL, ChKGK, sygn. 283, k. 66v).

122 Tamże, k. 66v.

${ }^{123}$ Tamże, k. 70. Ksiądz Horoszewicz nadmienił także, iż z braku odpowiedniej ilości miejsca lub (co bardziej prawdopodobne) pozwolenia duchowny innego wyznania grzebie ciała nie przy cerkwi, ale na prowizorycznym cmentarzu w polu, bez porzadku.

124 Tamże, k. 69.

${ }^{125}$ Doniesiono mi - pisał administrator - że przy furtach oparkanienia stoją namawiajacy do tego. Zapytatem diaka luchowskiego co znaczy choragiew do cerkwi przyniesiona i ten zamiar mi odkryt (tamże, k. 69). 
bez wynagrodzenia ${ }^{126}$. Postanowił też poczekać na kapłana z Luchowa zostawując czas do naradzenia się z nim. Ten jednakże nie chciał z nim rozmawiać, ale $z$ ludem swoim poszedt na cmentarz w polu z procesja $i$ ofiara. Wobec tego ks. Horoszewicz udał się do cerkwi, gdzie odprawił mszę dla swoich wiernych ${ }^{127}$.

Parafia babicka stała się zatem miejscem kuriozalnej sytuacji: dwóch księży, przedstawicieli dwóch wyznań, uważało się za jej prawowitych gospodarzy i duszpasterzy - odprawiało nabożeństwa i udzielało sakramentów. Jeden z nich był administratorem z ,nadania” władz carskich ${ }^{128}$ o czym nie wiedział drugi, działający na mocy prawa nadanego mu przez miejscowego biskupa ${ }^{129}$. Ksiądz Horoszewicz miał się jednak coraz częściej przekonywać, że władza państwowa stoi po stronie jego oponenta. Tak było m.in. 4 marca 1842 roku $^{130}$, kiedy do parafii osobiście przybył gubernator lubelski, gen. Albertow w towarzystwie m.in. komisarza obwodu krasnostawskiego, burmistrza Tarnogrodu, ks. Gintowta i inżyniera gubernialnego. W ich obecności zgromadzeni w domu Teodora Dubicy chłopi, ośmieleni obietnica$m i$ jeszcze raz potwierdzili chęć zmiany wyznania - deklarując przy tym całkowitą lojalność wobec cara i dziedzica - byleby Księdza i Cerkiew mieli. Skarżyli się także na administratora, twierdząc $i z$ jakoby zmusza ich do powrotu do dawnego obrząd$\mathrm{ku}$, co według nich jest prześladowaniem. Gubernator, po wysłuchaniu ich zeznań, obiecał im pomoc w budowie nowej cerkwi. Ksiądz Horoszewicz - relacjonujący to wydarzenie w raporcie do biskupa - odmówił podpisania protokołu z zebrania i przesłuchań wiedzac, że włościanie [...] prawdę ukrywająi13.

Nowe relacje o sytuacji w Babicach skłoniły biskupa do napisania skargi do namiestnika Królestwa Polskiego ${ }^{132}$, na nadużycia jakich, według tego, co hierarcha widział i czego zdążył się dowiedzieć, dopuścił się ksiądz Gintowt. Biskup opisał również niespokojności i odstępstwa od prawowitej wiary spowodowane działaniami prawosławnego duchownego ${ }^{133}$. Nie znając szczegółów, ani motywów wizyty gubernatora w Babicach, biskup Szumborski wysunął przypuszczenie, że wszystko, co czynił ksiądz Gintowt jest jego samodzielnym działaniem - ponieważ szczupte dochody z Luchowa okazały się dlań niewystarczające, swoja parafia umyślit pomnożyć i rozszerzyć kosztem innego duchownego ${ }^{134}$. Jednocześnie niepokój biskupa budziła postawa właściciela Luchowa ${ }^{135}$ wobec mieszkańców tej wsi, którzy poznawszy swa płochość chcieli wrócić do swojego dawnego wyznania i modlić się w cerkwi tarnogrodzkiej. Uniemożliwiono im to stawiając przy drodze warty, a także grożąc

\footnotetext{
126 Tamże.

127 Tamże.

${ }^{128}$ APL, ChKGK, sygn. 284, k. 9-12v.

129 Tamże, sygn. 283, k. 53-53v.

${ }^{130} 20$ lutego 1842 r. według kalendarza juliańskiego.

131 APL, ChKGK, sygn. 283, k. 68-68v.

13225 lutego/9 marca $1842 \mathrm{r}$.

133 APL, ChKGK, sygn. 283, k. 73-73v.

134 Tamże, k. 73v -74.

135 Generała Smirnowa.
} 
karami cielesnymi i sztrafami pieniężnymi ${ }^{136}$. Dlatego też biskup zwracał się z pokorna prośbą do namiestnika o zapobieganie dalszym nadużyciom ${ }^{137}$. Odpowiedzi nie uzyskał. Mógł się natomiast przekonać, z lektury kolejnych raportów administratora, że sytuacja w Babicach i okolicy staje się coraz bardziej napięta. Pod koniec marca, kilka dni po wizycie gubernatora, Teodor Dubica, jeden z prowodyrów zajść, przywłaszczył sobie 3,5 korca hreczki i 8 garnców owca ${ }^{138}$ z magazynu brackiego ${ }^{139}$, tudzież skarbonę cerkiewną, w której znajdowało się 40 złotych - również należącą do bractwa, którego był wcześniej prowizorem ${ }^{140}$. Kiedy ksiądz zażądał wydania sobie klucza do skarbony i przekazania ziarna innej osobie wspomniany Dubica zuchwale stawiając się odmówit, twierdząc, że exekucją nie jest zmuszony ${ }^{141}$. Tego samego dnia nieznani sprawcy zdemolowali dom Jerzego Zimnego (aktualnego prowizora), a jego samego pobili za to, $i \dot{z}$ powiedziat księdzu o ziarnie i kluczach. Gospodarz Jacenty Howsz został natomiast, za chęć powrotu do rodzimej wiary pobity przez sąsiadów, a następnie, pod naciskiem władz guberni, wydalony z Ordynacji ${ }^{142}$. Kilka dni po tych zajściach ksiądz Gintowt, wbrew wyrażonej woli, pogrzebał kolejnego włościanina ${ }^{143}$ i z pomocą Fedka Dubicy, cała wsia rządzacego przywłaszczył sobie ofiary pieniężne i chleby zaduszne przeznaczone dla wdowy i sierot ${ }^{144}$.

Na przełomie marca i kwietnia 1842 r., niemal równolegle do raportów księdza Horoszewicza, zaczęły napływać do biskupa wezwania (Ministerstwa Spraw Wewnętrznych i Duchownych oraz władz guberni) ${ }^{145}$ do przekazania cerkwi babickiej ze wszystkiem tem, co do nie należy [...] Wschodniemu Prawosławnemu Kościołowi, $\mathrm{z}$ powodu objawionego przez greko-unitów życzenia zmiany wyznania ${ }^{146}$. Biskup dwukrotnie ${ }^{147}$ odwoływał się od nich, tłumacząc, że nie może oddać cerkwi obce$m u$, wiedząc, iż wiele osób nie zadeklarowało przejścia na prawosławie ${ }^{148}$. W odpowiedzi generał-gubernator nakazał hierarsze wyznaczenie deputata ze strony jego diecezji ${ }^{149}$ do asystowania przy zgodnej z wola Najjaśniejszego Pana ${ }^{150}$ windykacji

136 APL,ChKGK, sygn. 283, k. 73v-74.

137 Tamże, k. 75.

138 Ok. 452 litrów ziarna.

${ }^{139} \mathrm{Na}$ zasiew jednego z pól, poddzierżawianych bractwu przez proboszcza.

140 Skarbnikiem.

141 APL, ChKGK, sygn. 283, k. 79-79v.

142 Tamże, k. 79 v -82.

${ }^{143}$ Co oznacza, że nie podjęto żadnych kroków związanych z pozwem cywilnym, złożonym przez biskupa w sprawie bezpłatnego udzielania posługi przez księdza Gintowta (APL, ChKGK, sygn.. 283, k.75-75v), nie wszczęto też postępowania karnego przeciwko niemu związanego z grzebaniem umarłych przed upływem 48 godzin od zgonu (tamże, k. 76).

144 APL, ChKGK, sygn. 283, k. 85-85v.

14523 marca/4 kwietnia (APL, ChKGK, sygn. 283, k. 77-77v), 25 marca/6 kwietnia (tamże, k. 78$78 \mathrm{v})$, oraz 27 marca/8 kwietnia 1842 r. (k. 83).

146 Tamże, k. 77-78.

14726 marca/7 kwietnia i 27 marca/8 kwietnia $1842 \mathrm{r}$.

148 APL, ChKGK, sygn. 283, k. 80v.-81.

$14931 \mathrm{marca} / 12 \mathrm{kwietnia} 1842 \mathrm{r}$.

${ }^{150}$ Nie można wzbraniać powrotu do prawosławnego Kościoła tym, których przodkowi należeli i tegocześnie dobowolnie tego żądają (APL, ChKGK, sygn. 283, k. 91-91v). 
cerkwi ${ }^{151}$. W wypadku odmowy biskup złamie porzadek rzeczy $i$ obowiazujace przepisy, naruszane już wcześniej skutkiem nietrafnego postępowania bytego proboszcza obrzadku unickiego w Babicach ${ }^{152}$. Tego samego dnia do Babic przybyło dwóch członków komisji egzekucyjnej z ramienia władz państwowych - komisarz obwodu zamojskiego i rachmistrz obwodu lubelskiego - z nakazem oddania cerkwi w administrację duchownemu prawosławnemu ${ }^{153}$. Mieli czekać z rozpoczęciem czynności - raportował ksiądz Horoszewicz - na przybycie delegata biskupiego oraz wyznaczonego nowego prawosławnego księdza ${ }^{154}$. Biskup odpowiedział kapłanowi, że deputata nie wyśle, gdyż przekazanie cerkwi innego wyznania kapłanowi, chociaż zgodne z prawem, jest sprzeczne z sumieniem. Natomiast ksiądz Horoszewicz w zaistniałej sytuacji powinien tak się zachowywać, aby nie robić niczego, co sugerowałoby aprobatę dla decyzji władz. Nie powinien też gwałtownie protestować, ani dopraszać się niczego oprócz stusznych pretensji dla wynagrodzenia pozostałym sierotom czyli żonie i dzieciom poprzednika ${ }^{155}$.

Oczekiwanie na biskupiego delegata trwało ponad tydzieńn ${ }^{156}$. Jeszcze przed nadejściem oficjalnej odmowy wyznaczenia go przez biskupa ${ }^{157}$ - rozpoczęto procedurę przejmowania cerkwi z apparatami, księgami, budynkami ekonomicznemi, gruntem, stużebnościami etc. Początkowo ksiądz Horoszewicz odmawiał delegatom zgody na przystapienie do czynności, jednak okazano mu dowód, że na termin dzisiejszy ma być delegowany żadany od biskupa ${ }^{158}$. Wobec tego, że do wieczora nie pojawił się nikt ze strony hierarchy, ani z Ordynacji delegaci postanowili na nich poczekać na plebanii, natomiast obecny na miejscu wójt gminy dostał od delegowanych polecenie postawienia warty ciagle czuwającej - dwóch ludzi przy cerkwi i dwóch przy plebanii - oficjalnie do ich pilnowania, a po szczególe abyśmy gnoju nie wywozili i drzewek owocowych nie wykopywali ${ }^{159}$. Administrator przedstawił delegatom stan beneficjum, w tym grunt prawie juz [...] zasiany lub sprawiany pod zasiew. $\mathrm{Na}$ to rachmistrz miał odpowiedzieć - napisał ksiądz Horoszewicz - iż Gubernator ustna dat instrukcję, iż zapłaconem będzie z Rządu za zboża zasiane. Administrator poinformował też delegatów, że zapłacił wszystkie wymagane przez państwo podatki i daniny ${ }^{160}$.

${ }^{151}$ Takowego Najwyższego Rozkazu Gubernator ani na moment wstrzymać nie może (tamże, k. 91v).

${ }_{152}$ Tamże, k. 91v, 99.

${ }^{153}$ Tamże, k. 86-86v.

154 Tamże.

${ }^{155}$ Tamże, k. 87-88 (list z 3/15 kwietnia).

${ }^{156}$ APL, ChKGK, sygn. 284, k. 39-42v (raporty komisarza obwodu).

${ }_{157}$ Tamże, sygn. 283, k. 93-93v. List biskupa do gubernatora (z 3/15 kwietnia), w którym z pokora i uległościa, lecz nie bez boleści serca przyjmuje carski rozkaz, odmawiając jednak stanowczo wyznaczenia delegata do przejmowania cerkwi przez duchownego innego wyznania.

$15831 \mathrm{marca} / 12$ kwietnia.

159 APL, ChKGK, sygn. 283, k. 93-93v.

${ }^{160}$ Tamże, k. 93v. 
4 kwietnia $^{161}$ do Babic przyjechał ksiądz Noskowicz z Brześcia Lit. z diakami z upoważieniem przez Rząd Gubernialny wydanym [...] installowania go na parocha Babic ${ }^{162}$ oraz upoważnieniem do nabycia zboża na zasiew u włościan lub $w$ administracji ordynackiej ${ }^{163}$. Na mocy tego dokumentu ksiądz Noskowicz miał zastąpić tymczasowego administratora, księdza Gintowta ${ }^{164}$. Tego samego dnia wieczorem dostrzegłem - relacjonował ksiądz Horoszewicz - że u drzwi cerkwi oprócz ciagłej z gospodarzy warty zawieszono kłódke [...] druga, jakiej dotąd nie było. Dlatego też, następnego dnia rano (w niedzielę) zażądał odpowiedzi od delegowanych, co by to znaczyło i kto zawiesił, na co odrzekli, że nie wiedza o tem $i$ że zapewne sami włościanie założyli kłódkę. Wówczas duchowny oskarżył ich o czyn gwałtow$n y$, który uniemożliwia przystęp do miejsca czci Boskiej ${ }^{165}$. Widząc, że prośba do delegatów o zdjęcie kłódki lub otrzymanie od nich jakichkolwiek wyjaśnień wydaje się niemożliwe, pojechał z wikarym do Różańca, gdzie wyspowiadał 72 osoby i odprawił Mszę Świętą ${ }^{166}$. Dzień wcześniej - 4/16 kwietnia - gubernator pisemnie upoważnił wyznaczoną delegację do odebrania cerkwi bez udziału przedstawiciela kurii chełmskiej ${ }^{167}$. Nakazał również biskupowi znaleźć inne pomieszczenie i fundusz dla wdowy po księdzu Bojarskim, ponieważ kapłan prawosławny który już przybyt na miejsce przeznaczenia jako obarczony liczna familia [...] niebyłby $w$ możności pomieścić się na plebanii z rodziną poprzednika ${ }^{168}$.

Do przejęcia cerkwi doszło - w sposób siłowy - 7/19 kwietnia. Tak relacjonował to zdarzenie ksiądz Horoszewicz: W dniu 7/19 b. m. dano mi znać w Różańcu, że włościanie babiccy odbijają Cerkiew tamtejszą. Udałem się z pośpiechem $i w$ istocie zastałem [ich] przy tym uczynku. Kłódki już nie było. Przemówiwszy do nich najłagodniej aby wstrzymali się cokolwiek, a ja sam wkrótce za nadejściem rozkazu odemknę, nie byłem stuchany. WW ni delegaci oddalili się do Łukowy i nie było komu powstrzymać. Przyprowadzony kowal babicki na widok mnie w milczeniu na progu cerkwi siedzacego nie śmiat przystapić, lecz inni coraz mocniej mnie szkalować

16116 kwietnia w kalendarzu gregoriańskim.

162 Wyznaczenie księdza Iwana Noskowicza na nowego „swiaszczennika” w Babicach - 18/30 marca 1842 r (APL, ChKGK, sygn. 284, k. 26-27) oraz Jerzego Iwanowa Zaleskiego na jego diaka (tamże, sygn. 32-32v). W poufnej korespondencji między kancelarią gubernatora, a metropolitą warszawskim przedstawiono ponadto dobre referencje księdza i jego psalmisty związane z ich bardzo dobrym wykształceniem oraz dotychczasową pracą na terenie diecezji brzesko-litewskiej.

163 APL, ChKGK, sygn. 283, k. 93-94.

164 Tamże, k. 93.

165 Tamże, k. 94-94v. Pod koniec raportu (z 3/15 kwietnia) ks. Horoszewicz sugerował, że cerkiew zamknięto, aby nikt $w$ nocy nie uwiózł Najświętszego sakramentu (tamże, k. 97).

166 Tamże, k. 94, 111. Wśród 72 osób było 37 kobiet, w tym najprawdopodobniej żony ,,buntowników” z rodzin: Fyków, Dubiców, Szłodzików, Pirogów, Rybałtów oraz mężczyźni, którzy pozostali przy unii m.in. prowizor Jerzy Zimny oraz szantażowana przez sąsiadów rodzina Howszów. Wiele osób sprawiało wrażenie zastraszonych i niepewnych.

${ }^{167} \mathrm{Na}$ początku kwietnia na plebanię w Babicach dotarł także biskupi nakaz ustąpienia księdza Horoszewicza z parafii (ale nie oddania cerkwi) i pełnienie posługi w Różańcu - datowany 30 marca/11 kwietnia 1842 r. (APL, ChKGK, sygn. 283, k. 84)

168 APL, ChKGK, sygn. 283, k. 95-95v. 
i sięgać ku zamkowi przez głowe moja zaczęli, a dwie kobiety ciagnać mię za ręce. Wtem bić zaczęty kobiety koło cerkwi stużaca plebańska, co dla wdowy po śp. plebanie i dziekanie wodę szklanka niosta, i gdy się schroniła za swa paniq od razów, uderzyty na nia, ścisnęty i poszturchaty pania, a stugę wyciagnęty na stronę za włosy. Na widok skrwawionej stugi i omdlałej na cmentarzu Matki, opuścilem dla ich ratunku drzwi cerkwi i uprzatnawszy pierwsza, poprowadziłem druga do mieszkania. Żandarm i urzędnik z obwodu W. Bialski, którzy ciagle dotąd byli na plebanii udali się tam na moje wezwanie, a ja nie szedłem, wstrzymali na chwile gwałt $i$ wrócili. Wójt gminy Łukowy przybyt z polecenia WW Delegowanych dla przekonania się, co by to było i nakazawszy milczenie opuścit niepostusznych. Po czem w pół godziny daja mi znać, że piszniami drzwi cerkiewne wyważaja, poszedtem znowu z żandarmem $i$ W. Bialskim i zastaliśmy dwie pisznie, które tak już drzwi odsadzili przez ludzi wyważane, iz ręka wolno by zmieściła się. Żandarm staną na warcie wstrzymując włościan. Za przybyciem $W W$ Delegowanych, ponieważ już gwałt został uczynionym $i$ drzwi ledwie że nie zupetnie otworzono, miałem oddać klucze, ale zastawszy drzwi nazad przymknięte, pisznie pochowane i reciąż na skubel na powrót zakładany, gdy mi także żadanego polecenia na piśmie komisarz odmówit, abym pod najsurowsza odpowiedzialnościq oddał klucze oświadczając, iż tego uczynić nie moge, oddalitem się sądząc, iż urzędników i żandarmerii ushuchaja gwałtownicy Domu Bożego, ale $w$ pót godziny potem daly się styszeć dzwony i w Cerkwi otworzonej gwaltem duchowni prawosławni rozpoczęli nieszpory. Nazajutrz zostatem wezwanym do Babic i na okazanie rozkazu gubernatora aby nie czekajac na delegowanego od JW. Pana ${ }^{169}$ przystapiono do czynności, gdy już w cerkwi spowiadano, klucze komisarzowi oddatem, a sam do przeniesienia Sanctissimum zabierałem się z ks. Kozłowskim, ale nas do tego nie dopuszczono, gdyż lud ciemny swoim gwaltem zagrażat, przeto 7 osób z pozostałemi przy rodowitem obrzadku spożyto, poczem wedlug woli JW. Pasterza przemówiwszy do ludu opuściliśmy cerkiew po Mszy i dziękczynnem nabożeństwie mianem przez duchowieństwo obrz. g. ros. ${ }^{170}$ Po „oddaniu” cerkwi ksiądz Horoszewicz uczestniczył jeszcze, chociaż nie miał takiego obowiązku, w zdaniu rzeczy cerkiewnych ${ }^{171}$, a także sporządził listę pretensji wdowy po księdzu Bojarskim ${ }^{172}$.

8/20 kwietnia 1842 r. unicki duchowny, przebywający już w Różańcu, otrzymał od komisarza obwodu zamojskiego polecenie natychmiastowego przekazania ksiąg stanu cywilnego księdzu Noskowiczowi i natychmiastowego udania się do Chełma celem otrzymania dalszego przeznaczenia od biskupa ${ }^{173}$. Ksiądz Horoszewicz odpowiedział, że zarówno jego los (od 10 lat kooperatora w Różańcu), jak i los ksiąg

\footnotetext{
${ }^{169}$ Czyli od biskupa Szumborskiego.

${ }^{170}$ Raport z 9/21 kwietnia 1842 r., APL, ChKGK, sygn. 283, k. 100-100v.

${ }_{171}$ Jednakże dla spokojności, aby nie odpowiadać za ewentualne szkody czy braki, pozostał jeszcze przez pewien czas przy cerkwi objaśniwszy o budynkach i zasiewach (tamże, k. 100v).

${ }_{172}$ Czyli listę ruchomości i nieruchomości należących do rodziny zmarłego parocha (APL, ChKGK, sygn. 283, k. 109-110).

${ }^{173}$ APL, ChKGK, sygn. 283, k. 101, 102-102v.
} 
metrykalnych pozostają w wyłącznej gestii biskupa, do której nie wolno mieszać się władzom państwowym ${ }^{174}$. Unicki duchowny nie podpisał również protokołu zdawczego oddania cerkwi pod zarząd $x$. Gintowta ${ }^{175}$, ani protokołu przekazania jej księdzu Noskowiczowi ${ }^{176}$. Czynił to na wyraźne polecenie biskupa, który uznał, $i \dot{z}$ cerkiew ze sprzętami kapłańskiemi, ubiorami i z tym wszystkim co się w niej znajdować mogło gwattownie odbita z nadwerężeniem drzwi została i na użytek zabrana była prawosławnych nie może przeto biskup [...] mieszać się $w$ attrybucje innego obrzadku duchowieństwa ${ }^{177}$.

Ostatnim ,akordem” wydarzeń babickich było przybycie do Różańca 4/16 grudnia 1842 r. - pod nieobecność księdza Horoszewicza, wówczas już administratora parafii różanieckiej - księdza Gintowta i księdza Noskowicza z burmistrzem Tarnogrodu i zastępcą wójta gminy Łukowa. Zapytali oni księdza Kozłowskiego (wikariusza) o świadectwo $i$ upoważnienie władz do pobytu, on zaś okazał im żądane dokumenty. Następnie zwołano parafian i burmistrz oświadczyt, iż wola jest Rzadu aby parafianie do najbliższej cerkwi o postugi duchowne udawali się, że zaś jest tu filia parafii babickiej więc akta otrzyma paroch Babic i parafianie należeć do niego będą. Na to jednomyślnie włościanie oświadczyli, iż tego zupetnie nie chca $i$ że mając sobie od biskupa przesłanego księdza tym się kontentują w miejscu ${ }^{178}$. Wobec takiego oporu delegaci zmuszeni byli odczytać protokół suspensji czyli zawieszenia przez władze w czynnościach księdza Horoszewicza ${ }^{179}$. Jednak chłopi, mimo wyraźnego nakazu, nie chcieli go podpisać obawiajac się zdrady ${ }^{180}$. Po długim przekonywaniu przez delegatów pięciu chłopów zdecydowało się na postawienie krzyżyków na przygotowanej liście, zastrzegając jednak, że robią to na zaręczenie tylko ks. Koztowskiego ${ }^{181}$.

Po powrocie z Chełma ksiądz Horoszewicz dowiedział się jeszcze, że w pobliskiej łacińskiej parafii Tarnogród prawosławni duchowni zaczęli attendować przy

174 Tamże, k. 105-105v. Administrator otrzymał od swojego zwierzchnika polecenie, aby dopiero po sporządzeniu odpisów sukcesywnie oddawać proboszczowi Babic metryki, ale tylko te związane z tą wioską. Metryki nie związane z Babicami, bądź pochodzące z czasów austriackich miał zachować na plebanii w Różańcu (tamże). Korespondencja dotycząca akt stanu cywilnego trwała niemal 5 lat (1842-1848). Władze (Ministerstwo Spraw Wewnętrznych i Duchownych oraz Rząd Guberni Lubelskiej) powtarzały, że nowy duchowny w Babicach powinien otrzymać stare księgi do kontynuacji, a biskup unicki uważał, iż należy sporządzić nowe, gdyż parafia należy do innego wyznania, brak zatem ciągłości duszpasterskiej (zob. APL, ChKGK, sygn. 283, k. 101-102, 116-139). Ostatecznie ksiądz prawosławny otrzymał kopie dokumentów, przepisane przez jednego z różanieckich wikariuszy, jednak przez wiele miesięcy ,zapominał” o tym poinformować swoich zwierzchników, co powodowało kolejne monity władz adresowane do księży unickich (tamże, k. 130-130v, 139-142).

${ }^{175}$ APL, ChKGK, sygn. 284, k. 51-69 (z 8/20 kwietnia 1842).

176 Tamże, k. 59v.-60 (z 9/21 kwietnia 1842).

177 APL, ChKGK, sygn. 283, k. 124v.

178 Tamże, k. 117-117v.

${ }^{179}$ Został przeniesiony przez biskupa do parafii Kossobudy (W. Kołbuk, Duchowieństwo unickie w Królestwie Polskim, s. 132).

${ }^{180}$ Aby podpisów nie użyto na cel odmiany ich rodzimego obrządku (tamże, k. 117v).

181 Tamże. 
niektórych nabożeństwach. Administrator unickiej parafii Różaniec (czyli ks. Horoszewicz) podejrzewał, że może to mieć związek z podwyższeniem stawek mesznego płaconych łacinnikom przez niektórych jego wiernych. Oznaczałoby to, że grecko-rosyjscy księża szukali nowych sposobów przeciągnięcia na swoją stronę kolejnych „dusz”182. Starania te nie przyniosły jednak efektów - parafia Różaniec pozostała unicka jeszcze przez trzy dekady, do zniesienia unii w 1875 roku $^{183}$.

Niemal równolegle do „przejmowania” Babic i Różańca władze carskie, wspólnie z hierarchią prawosławną, starały się przejąć majątek i wiernych cerkwi w Potoku Górnym. Tym razem jednak jako główny argument, mający przekonać włościan do powrotu do wiary pradziadów wykorzystano znaczną odległość (ok. 4 wiorst) dzielącą ich od świątyni w Lipinach, w której - od zamknięcia (w 1839 r.) zrujnowanej cerkwi w swojej miejscowości - spełniali praktyki religijne. Tym razem jednak starania władz nie przyniosły większych efektów. Przejście na prawosławie zadeklarowała niespełna połowa mieszkańców Potoka ${ }^{184}$ oraz kilkanaście „dymów” w Kulnej. Reszta deklarowała pozostanie przy unii, domagając się rewindykacji dawnej cerkwi lub przynajmniej jej wyposażenia ${ }^{185}$.

W kolejnych latach natomiast część „nawróconych” mieszkańców nowych parafii powróciła do unickiego obrzadku. Nie były to liczne grupy, przynajmniej jeśli wierzyć oficjalnym statystykom prowadzonym przez prawosławnych duchownych, niemniej samo występowanie tego zjawiska świadczy o niezbyt głębokim ukorzenianiu grecko-rosyjskiej wiary w południowej części Lubelszczyzny. Jedni odchodzący od prawosławia tłumaczyli swój krok zmianą miejsca zamieszkania i związaną z tym odległością od dotychczasowej świątyni, inni zmianą stanu cywilnego i przyjęciem wyznania współmałżonka - te dwa czynniki przeważnie występowały razem. Część osób natomiast, nie podając wyjaśnień, niemal z dnia na dzień przestawała uczestniczyć w praktykach religijnych w cerkwi prawosławnej, przenosząc się do innej, w której posługę sprawowali duchowni uniccy. Najmniej liczni zostawali „łacinnikami”186.

Sukces władz rosyjskich, zachęcających do porzucania unii cerkiewnej na rzecz prawosławia, okazał się zatem połowiczny, można wręcz powiedzieć wątpliwy.

\footnotetext{
${ }^{182}$ Tamże.

${ }^{183}$ Pozostając przy tym dosyć dobrej kondycji finansowej (zob. APL, ChKGK, sygn. 465).

${ }^{184}$ Według spisu z 1846 r. we wsi Potok były 103 domy łacinników, 31 unitów i 28 prawosławnych, (APL, WDKP, sygn. 46, k. 88v).

185 APL, WDKP, sygn. 46, Ob. Ustrojeni w siele G. Potokie prawosławnoj cerkwi 1843-1855, k. 69$69 v$. Podobno na „opornych" niemal nie skutkowały nawet obietnice zniesienia podatków, por. tamże, k. 68-69, E. Likowski, Dzieje kościoła unickiego, s. 268.

${ }^{186} \mathrm{~Np}$. w Luchowie już w latach 1842-1843 od prawosławia odeszły 24 osoby, większość była spokrewniona i spowinowacona (APL, WDKP, sygn. 92, k. 2 - 2v); w Potoku w latach 1843-1850 - 45 osób porzuciło prawosławie, m.in. rodzina Mandziarowskich w Goździe i Biłgoraju i Ewa Paszkowa zamężna w Lipinach (APL, WDKP, sygn. 59, k. 25-29 i 53). Dla Babic nie posiadamy danych tego rodzaju. Wiadomo natomiast, że najbardziej zagorzali zwolennicy zmiany wyznania uzyskali (w 1844 r.) pozwolenie na budowę nowej cerkwi i założenie przy niej bractwa (APL, ChKGK, sygn. 284, k. 146$146 v, 153-157)$.
} 
Osiągnięto go głównie dzięki wykorzystaniu sprzyjającego splotu okoliczności społecznych, religijnych i ekonomicznych - dzięki słabej, nie ugruntowanej świadomości religijnej chłopów (chodzących do tej cerkwi, która była najbliżej), ich problemom finansowym, skłonności części z nich do pieniactwa i nadużywania trunków, a także braku większego zainteresowania ich świątyniami (w tym ich stanem technicznym) i wyznaniem (ewentualnie ,zainteresowania” zmianą tegoż) ze strony dziedziców oraz bliskości granicy z Galicją, skąd sprowadzono jednego z prawosławnych kapłanów, prawdopodobnie dawniej związanego z obrządkiem greckokatolickim ${ }^{187}$. „Punktowa” likwidacja unii cerkiewnej w diecezji chełmskiej nie sprawdziła się. Nie oderwano żadnej parafii w całości: administracja większej części dawnej parafii babickiej została przeniesiona do Różańca, od Tarnogrodu oderwano tylko filię (Luchów), a w Potoku połowa ludności oparła się propagandzie i machinacjom ${ }^{188}$ władz cywilnych i duchownych. Niemniej wydarzenia lat 1840-1842 stanowiły poważne memento tak dla duchowieństwa, jak i dla wiernych - ostrzeżenie z którego wielu z nich zaczęło zdawać sobie sprawę i przypominać sobie o nim, w obliczu groźby kasaty unii albo nawet już po jej likwidacji (lata 60-te i 70-te XIX w.).

${ }^{187} \mathrm{O}$ księdzu Ignacym Gintowcie prawie nic więcej nie wiadomo, ponad to co można dowiedzieć się z akt ,sprawy babickiej”. Można jednak przypuszczać, że jego osobowość i droga życiowa mogła być podobna do tych ponad stu duchownych greckokatolickich, którzy sprowadzeni zostali z Galicji na przełomie lat 60-tych i 70-tych XIX w. na ziemie nadbużańskie i dla korzyści materialnych stali się tu apostołami prawosławia (zob. W. Kołbuk, Duchowieństwo greckokatolickie wobec likwidacji unii w diecezji chetmskiej, „Zeszyty Naukowe KUL”, t. 27, 1984, nr 4(108), s. 65-75.

188 Określenie J.P. Bojarskiego, Czasy Nerona, s. 23. 